\title{
Challenges Militating against Sustainable Economic Development Potential of African Aromatic, Beverage and Medicinal herbs: A South African Perspective
}

\author{
Spiers Unati', Nkomo Mpumelelo', Ngezimana Wonder², Antwi Akwasi Michael'1, and Fhatuwani \\ Nixwell Mudau' ${ }^{1}$ \\ ${ }^{1}$ Department of Agriculture and Animal Health, University of South Africa, Private Bag X6, Florida, 1710, South Africa. \\ ${ }^{2}$ Department of Crop Science, Marondera College of Agricultural Science and Technology, University of Zimbabwe, P. Box 35, \\ Marondera, Zimbabwe.
}

\begin{abstract}
Context: Medicinal and Aromatic plants (MAPs) extracts have become an essential part of exports in the developing countries. Due to the rich diversity of MAPs and as consumers of natural products increase, there is a potential to exploit this niche market. Aim: The objective(s) of the study was to identify and analyze challenges militating against economic development potential of African aromatic, beverage and medicinal herbs industry. Settings and Design: The study was undertaken in three (3) provinces (Limpopo, Mpumalanga and the Western Cape) of South Africa. The population included all men, women and youth involved in production/harvesting and trading of MAPs. Four focused groups of randomly selected 30 individuals per group from the list of resource constrained farmers provided by local extension officers were formed per province. Materials and Methods: Using desk-top reviews, focus group discussions and key stakeholders' interviews, the study employed holistic and participatory methodologies to examine aspects of African medicinal and aromatic agricultural industry in South Africa. Triangulation of qualitative data gathered from previous research and reports, interviews, focus group discussions and industry visits observations were done. Information was gathered from primary users of agricultural technologies, while information on technology development and use was from developing farmers. Key government units relating to agricultural medicinal and aromatic industry were consulted and reports used to verify findings from focus group discussions. Secondary data was from literature review, namely; annual reports from the Agricultural extension (Agritex) office, non-governmental organizations and research institutions. The majority of the data/information sources pointed to the need for encouragement towards cultivation of MAPs as field and horticultural crops. Statistical analysis used: All the data from focus group discussions, key informant interviews, secondary data and field visit observations was consolidated (the South African perspective) and analyzed using Atlas software to summarize the data. Information from the key informants' interviews was used to triangulate information gathered from the desktop review and focus group discussions. Results: Major challenges observed from the study included; very lowyielding species, poor quality outputs and poor processing methods. In addition, most MAPs do not adhere to agricultural propagation practices, deterring them as desirable crops. Moreover, there are many differences in traditional medicines so produced in respect of quality. Determining the right medicinal concentrations, dosage and toxicity concerns require highly efficient modern technologies. Other issues of concern revealed included, intellectual property rights, lack of access to information, marketing of products and sustainable conservation. Conclusion: The preference by consumers to have natural products has grown over the years. This increases annually and has allowed medicinal, aromatic plants to present a unique and niche market base for pharmaceuticals, cosmetics and other industries (food \& industrial use). South African farmers can exploit this new industry to grow the sector, create jobs and increase economic development.
\end{abstract}

Submission Date : 03-12-2014

Revision Date : :22-06-2015

Accepted Date : :19-07-2015

DOI: 10.5530/ijper.50.1.11 Correspondence Address Fhatuwani N. Mudau Department of Agriculture and Animal Health,

College of Agriculture and Environmental Science, Private Bag X6, Florida 1710 , South Africa.

Phone numbers +2711471 $3231 / 2289$

E-mail address mudaufn@ unisa.ac.za

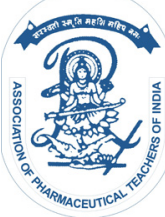

www.ijper.org 
Key words: Medicinal Aromatic Plants, Commercialization, Challenges, South Africa.

Key Messages: Medicinal and Aromatic plants (MAPs) extracts have become part of commercial exports in developing countries. This study identified and analyzed challenges militating against economic development potential of African aromatic, beverage and medicinal herbs industry.Several challenges were identified and the possible solutions to enhance product quality and economic development.

\section{INTRODUCTION}

South Africa has been unable to provide adequate employment, ${ }^{1}$ and unemployed rates in fact have increased. ${ }^{2}$ With this as the backdrop, the New Growth Path (NGP) specifically calls for more inclusive growth, and "heightened efforts to strengthen partnership among all economic role-players, proceeding from the understanding that each sector has a critical role to play in addressing these challenges."

Agriculture, Forestry and Fisheries (AFF) are widely recognized as sectors with significant job creation potential and with strategic links to beneficiation opportunities. However, between 1994 and 2012, the real contribution to GDP (Gross Domestic Product) of AFF increased by $29 \%{ }^{3}$ Agriculture plays critical roles in the economies of many developing countries. In South Africa, as in many developing countries, agriculture contributes greatly to employment. According to National Agricultural Marketing Council annual report ${ }^{4}$ and Economic sciences, ${ }^{5}$ the agricultural sector has a labour multiplier that outperforms all other sectors. In South Africa about 6 million people's livelihood is contingent on agriculture. This is about $10 \%$ of the South African population. ${ }^{6}$ Agriculture also contributes to food security, exports \& imports, GDP, foreign exchange and as a strong stakeholder in its backward and forward linkages with the machinery, petroleum and chemical industries through its continuous purchases of its capital and production inputs and a supplier of raw materials for food and non-food processing. Despite the aforementioned critical roles of the agricultural sector, its support from the government has not been very encouraging. As a result of this, the South African agricultural sector's overall growth over the past 30 years has been a minimal of $1.7 \%$ and its contribution to the GDP has been on the decline since the manufacturing and services sector have grown far bigger than agriculture. ${ }^{7}$

Governments of USA, Japan, South Korea and the European Union (EU) that are classified as wealthier countries and regions, use different forms of support and subsidies for their farmers. These policies serve to: transfer income from consumers and tax-payers to farmers, heavily protect those countries from more open international trade thereby protecting local producers, stabilize food prices, improve returns on farm investment, support rural development and improve national food self-sufficiency and food security. ${ }^{7}$ Organization for Economic Co-operation and Development (OECD), ${ }^{7}$ indicates producer support estimate of South Africa as $5 \%$, USA $20 \%$, OECD $31 \%$, EU $34 \%$ and Japan $58 \%$. Governments of developing countries including South Africa do not also offer meaningful support to agriculture in other areas such as research, infrastructural development and marketing. It is a known fact that research and development $(\mathrm{R} \& \mathrm{D})$ has positive impact on productivity and reduction of poverty. ${ }^{8}$ However, in developing countries, only $2 \%$ of $R \& D$ budgets are allocated to agricultural research contrary to that of USA where $50 \%$ of R\&D budget is allocated to agricultural research. Due to the importance of agriculture and its R\&D, NEPAD in 2003 indicated that at least 10\% of national budgets should be allocated to agricultural development. ${ }^{\text {? }}$

Many Africans and other people in developing countries use medicinal and aromatic plants for treatment of several diseases including: malaria, diabetes, mental disorders, cancer, hypertension and human immunodeficiency virus/acquired immunodeficiency syndrome. ${ }^{10}$ The researchers indicated that the Phytochemical screening of these plants revealed that they contain bioactive chemical substances such as alkaloids, tannins, saponin, and others with therapeutic potentials. The paper explains further that the active ingredients of medicinal and aromatic plants can be found either in the roots, leaves, stems, flowers or bark and can be extracted using an appropriate extraction method. The study however, caution that despite the benefits derived from plants, some of them have some unpleasant side effects which may be related to over doses or other factors which may lead to acute toxicity and death. The conclusion by the researchers was that if these problems are carefully addressed, will help to harness the therapeutic potentials of medicinal and aromatic plants for further drug development in the future. The integration of traditional medicine in primary health care and the growing interest in many Western countries in Complementary and Alternative Medicine (CAM) point to a positive future for MAPs. ${ }^{11}$ Traditional medi- 
cine in terms of a culture-bound body of indigenous medical knowledge, belief and practices has provided the primarily plant-based foundation for many ethno medical systems which already existed long before the development of 'scientific' or cosmopolitan medicine. ${ }^{12}$ In the new policy by the South African government called the Diseconomy Strategy, medicinal and aromatic plants will play a role in the economic turn around and its growth. Bio-economy encompasses biotechnological activities and processes that translate into economic outputs, particularly those with industrial application. Within the South African context these may include, but are not limited to, technological and non-technological exploitation of natural resources such as animals, plant biodiversity, micro-organisms and minerals to improve human health, address food security and subsequently contribute to economic growth and improved quality of life. Department of Science and Technology indicated in its Bio-economy Strategy of unlocking the value of indigenous crops, coupled with consumer demand for natural products, which presents opportunities for South Africa to capitalize on its biodiversity and capture niche markets. ${ }^{13}$

The Agricultural and forestry value chain has been also targeted as one of the job drivers in the New Growth Path of South Africa. By this the New Growth Path intends to create new jobs in the knowledge intensive sectors including pharmaceuticals and biotechnology. This will also involve more research and innovation of processing of African medicinal and aromatic plants. Therefore the need for development of the African medicinal and aromatic plants of the agriculture and forestry/biological resources sub-sector cannot be overemphasized. However, the government increased public and private spending on $\mathrm{R} \& \mathrm{D}$ from $0,93 \%$ in $2007 / 8$ to only 1,5\% in 2014 and $2 \%$ in $2018 .{ }^{14}$

Literature exists regarding challenges and constraints of the African medicinal and aromatic plants. Common among the challenges is the decline of some important MAPs due to incessant abuse of many species of the MAPs such as over-harvesting leading to the destruction of the habitats. Other human activities such as slashing and burning of vegetation/forest through shifting cultivation also augment destruction of the species habitats. Other major causes which lead to the high value MAPs species decline include: narrow range of distribution, land use disturbances, introduction of nonnatives, habitat alteration, climatic changes, heavy livestock grazing, explosion of human population, fragmentation and degradation of population, population bottleneck, and genetic drift. The study by Kumari et al..$^{15}$ further indicates that natural enemies such as, pathogens, herbivores, and seed predators could substantially limit the abundance of rare medicinal plant species in any given area. Since most people in developing countries use MAPs as sources of medicine and food, through indiscriminate harvesting it could be stated that all things being equal, increases in human population in developing countries will surely endanger more high value MAPs.

The food-processing sector is the largest manufacturing sector in employment terms in South Africa, with 183,502 employees and it contributes a significant 3.1\% of manufacturing value as percentage of GDP of the country. ${ }^{3}$ The sector has been identified in the Industrial Policy Action Plan (IPAP) as one of the areas with a potential to actualize Macroeconomic objectives as pronounced in the New Growth Path (NGP). ${ }^{3}$ A key characteristic of the agro-processing is its strong up- and downstream linkages. Upstream, the sector links to primary agriculture across a wide variety of farming models and products. Downstream, agro-processing outputs are both intermediate products to which further value is added and final goods that are marketed through wholesale and retail outlets, as well as through a diverse array of restaurants, and fast-food franchises making it critical for employment creation and poverty eradication. ${ }^{14}$ Therefore, the objective of the paper is to establish the challenges militating against the realization of the economic development potential of the African medicinal and aromatic plants and highlight the importance of this sector both on the economic and legislative fronts. It also highlights the possible solutions that can be applied at various level of the value chain.

\section{SUBJECTS AND METHODS}

The study employed holistic and participatory approaches to comprehensively examine all aspects that relate African medicinal and aromatic agricultural industry in South Africa. The study was undertaken in three (3) provinces (Limpopo, Mpumalanga and the Western Cape). The population of the study included all men, women and youth involved in production/harvesting and trading of AMAP in the selected provinces. Four focused groups of randomly selected 30 individuals per group from the list of resource constrained farmers provided by local extension officers were formed per province. This translates into 120 respondents per province and 360 in total. Focus group discussions and interviews were used to gather the data/information. Focus group discussions were held in each of the three provinces using a semi-structured guide or data/ 
information collection tool/instrument. To avoid biasedness, the researcher employed trained enumerators and facilitators in the focus group interviews.

The study benefited from triangulation of qualitative data gathered from previous research and reports, interviews, focus group discussions and industry visits observations. The study used collected information from the primary users of agricultural technologies, while other information about technology development and use was gathered from various stakeholders ranging from developing farmers and immergence of the herbal industry. Key government units relating to agricultural medicinal and aromatic industry were also consulted and reports used to verify findings from focus group discussions. Thus, the study used both secondary and primary information/data. The research made use of secondary data from review of literature through a desktop study of published and unpublished resources. Secondary information was also gathered from annual reports from the Agricultural extension (Agritex) office, non-governmental organizations, research institutions and academic work of individuals. The information gathered from the desk review was also used to inform the selection of the sites for conducting focus group discussions and mapping the various key informants to be interviewed. This also informed the research in terms of existing information gaps and the identification of areas for further investigation.

Other tools used in gathering information during focus groups discussions included resource mapping, time and trend analysis, stakeholder mapping and priority and ranking. Resource mapping was used to collect information about the various resources and opportunities available for the farmers. Information was also gathered through interviews with officials from agricultural extension department both at provincial and district levels. Personal life stories were also used to develop deeper understanding of the study population and how they have related to African medicinal industry over time. All the data from focus group discussions, key informant interviews, secondary data and field visit observations was consolidated (the South African perspective) and analyzed using Atlas software to summarize the data. Information from the key informants' interviews was used to triangulate information gathered from the desktop review and focus group discussions.

\section{RESULTS AND DISCUSSION}

The information/data analysis benefited from comprehensive triangulation of information coming from different sources and conclusions were drawn from all existing evidence. Decisions on each of the identified challenges in Table 1 were based on the group's consensus view of $60 \%$ and above through the focus groups' discussions which were also consistent with the views from the secondary sources. Suggested strategies provided by the sources that can be employed to mitigate the respective challenges and constraints were also compiled and presented in Table 1 which depicts a spectrum of bio-physical, production, marketing, financial, policies, value adding, R\&D, post-harvest, environmental and socio-economic effects. The challenges and constraints facing the African medicine and aromatic plants industry as identified by the study (Results in Table 1) include:

\section{Absence of efficient, sustainable conservation and cultivation methods}

Majority $(70 \%)$ of the focus group participants and the other secondary sources pointed to the above challenge as one of the major ones and suggested the encouragement of cultivation of MAPs as field and horticultural crops in gardens and farms and that those government departments of developing countries concerned with conservation of water, vegetation/forest should prioritize MAPs. Contrary to this finding the South African government's policy for the protection and conservation of medicinal and aromatic plants do not take high priority on the agenda for natural resources management ${ }^{14}$ The government programmes give priority to agricultural and wildlife resources. By growing MAPs in the form of gardens and farms for primary agriculture will not only ensure proper farm management practices of the species but the prevention of threat of extinction of several MAPs species through use of haphazard harvesting and inefficient, ineffective post-harvest management practices. The primary production approach similar to production of staple crops may further lead to economic production levels of the MAPs to favour manufacturing; hence the prioritization of the protection and conservation of the MAPs by the concerned governments' departments cannot be overstated, especially in the area of research and information availability.

\section{Challenges of low-yielding, poor quality outputs, poor adaptation to farming production systems and very little research and development}

Some of the major challenges among the results of the study were very low-yielding species, poor quality outputs and poor processing methods. In addition, most of the MAPs do not adhere to modern agricultural propagation practices. Compounding the problems is that there is little or no research on the improvement of the lowyielding species and adaptation to farming production systems in most of the developing countries. Many 


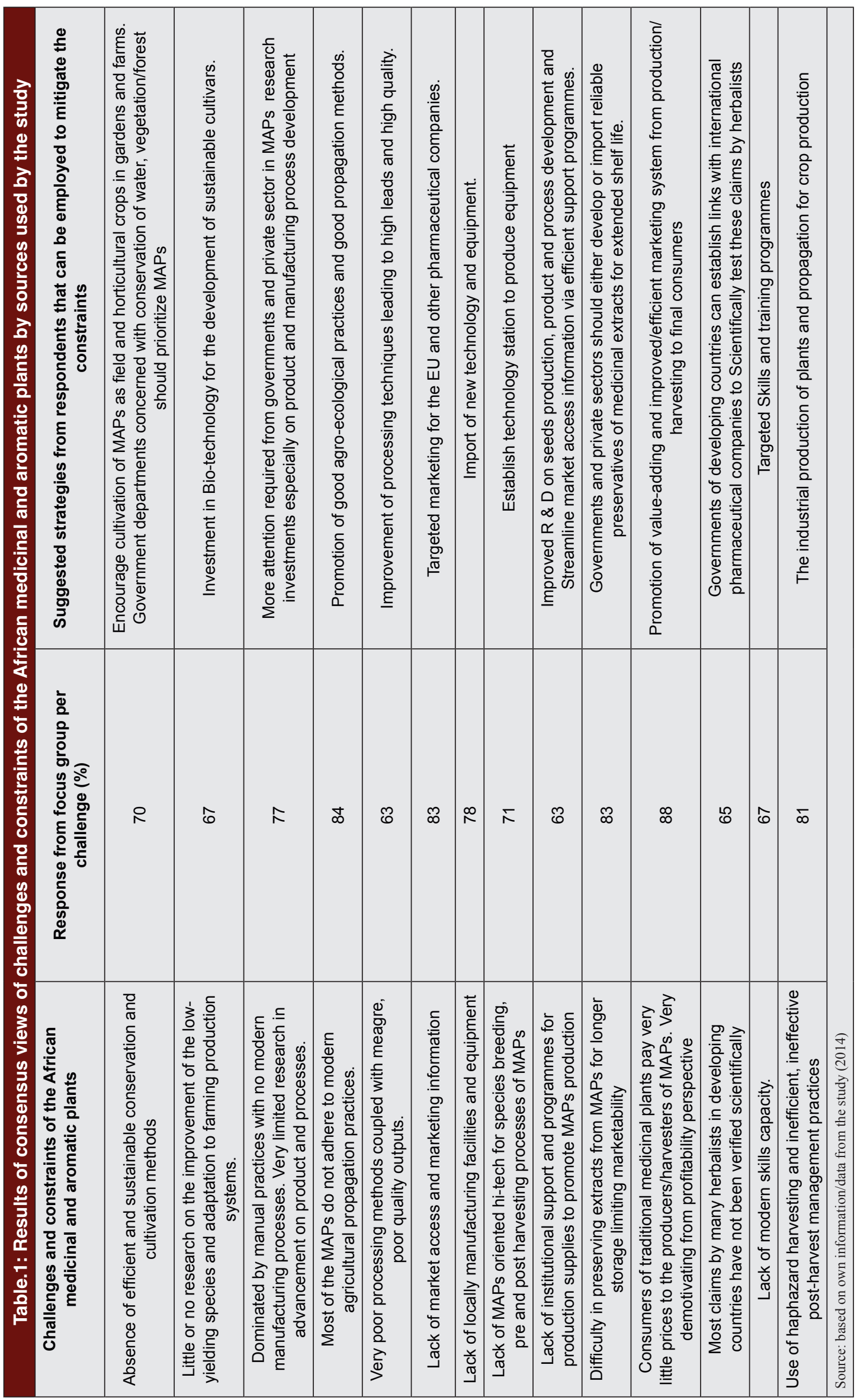


(67\%) of the focus group participants and the other secondary sources were of the view that the aforementioned challenges have not been given the desired priorities by the governments of Less Developed Countries (LDCs) in national investment, research and export development. Most Least Developed Countries (LDCs) concentrate their research and development on staple crops such as maize, rice and wheat. The lack of attention from the various governments of the LDCs may be attributed to many reasons. The researchers Kideghesho et al. ${ }^{16}$; Adotey et al. ${ }^{17}$ indicated the lack of scientific proof to the effect that the active elements in medicinal plants are valuable, not dangerous and effectual. This is very important for the medical field and the public to endorse the use of African medicinal plants as highly acceptable alternatives to western medications; and this will in turn induce more research and development investment from government and private sectors as well as international collaboration. However, methods to be used to evaluate the safety and effectiveness of traditional medicine are new challenges, which have emerged in recent years. There is lack of research mainly in the improvement of high-yielding species and the adaptation of them to gardening and farming cultivars for primary agriculture. In many LDCs especially in Africa, there is very little local support for research and development of MAPs. Greater part of the little support available is usually obtained from external sources. The situation is often exacerbated by inadequate infrastructure/facilities such as water, electricity, transport and communication, as well as manpower, technical resources and financial capital for investment. Highly required are investment in Bio-technology for the development of sustainable cultivars, more support for research and training activities for traditional medicine and the promotion of good agro-ecological practices and good propagation methods. The research and development recommendations suggested will be more attainable if supported with the proper policies.

Domination by manual practices with very little modern product manufacturing processes and lack of appropriate technology for post-harvest and preprocessing purposes

Most (77\%) of the respondents of the focus group and the other sources agreed that traditional herbal medicines and aromatic products are formed by the practitioner him/herself who identify and harvest the right plant species. Thus in most cases the practitioner is the only one who knows the right species, he does the harvesting himself, and do the preparation of the medicines himself; all the processes done manually. Since all the processes are done manually, there is no guarantee of the genuineness, concentration levels of the potential elements in the herbal medicines and quantity of plant material used in the preparations. There are many differences in traditional medicines so produced in respect of quality. Determining the right medicinal concentrations, dosage and removal of toxic contents require highly efficient modern technologies. These are critical challenges to the realization of the full potential of the MAPs as alternative to western medicines. Therefore the need for investment by LDCs for efficient and effective techniques, manufacturing practices and appropriate technology for post-harvest and preprocessing purposes for African medicinal and aromatic plants cannot be over-emphasized.

\section{Marketing of products challenges}

Marketing involves the movement of goods and services from the producer to the final consumers. In every commercial production or service the market is the main determinant of sustainability. No matter how much bountiful production is, the market is the adjudicator. The market outlets can be for local use or export. Some of the marketing challenges of MAPs identified by the study include;

- inability of producers/harvesters to have contract agreements for supply due to lack of volume that can be produced by small industries.

- inability to access market information.

- poor preservation of medicinal extracts for extended shelf life and.

- low prices paid for traditional medicinal plants by herbal medicine traders and urban herbalists as identified by $(88 \%)$ of focus group participants and the other secondary sources.

Marketing is not just about selling but requires a clear and perfect understanding of what consumers want and the ability to deliver it to them through the most appropriate channels for a profit. ${ }^{18}$ The marketing functions comprise identifying the target market, product design, pricing, promotion, transportation (distribution), storage, and financing. Selling directly to retail outlets requires a routine sales route as well as an adequate volume of the product to meet market demand. Wholesaling requires larger volumes over a longer period to provide consistency of quality and supply. Strict grade, size and quality standards are required by the wholesale and retail markets. This often necessitates the use of packing and grading facilities. Unforeseen risks may limit production and profitability of African medicinal and aromatic plants. Unstable markets, low product prices, changing tastes, poor infrastructure, droughts, inadequate government 
policies, longer food preparation time, as well as competition from non-African medicines and aromatic products are common risks faced by these plant-based industry markets. Most (83\%) of the focus group participants and the other secondary sources identified lack of market access and information as a major challenge to the economic development of MAP. Government's support in the form of market information availability to the suppliers and buyers in this industry would go a long way in improving the marketing of the plant-based industry. Good preservation of African medicinal and aromatic extracts for extended shelf life will help reduce losses and also spread supply and maintain prices across seasons and this was highlighted by $83 \%$ of focus group participants and the other secondary sources.

Regarding export market, usually medicinal plants are allowed without any tariff restrictions in many countries; medicinal plants are mostly exempted from import duty in some developed countries including Canada, Japan, the European Union and the USA. ${ }^{19}$ However, tariff charges in China and South Africa vary between 10\% and $20 \%$ of the value of goods, depending on product and origin, while Japan levies a $5 \%$ tax on imports of ginseng roots, peppy straw, sandalwood and some others. ${ }^{20}$ Threats to the future development of medicinal plant exports from LDCs depend on the structure of the major importing markets.

Efficient and effective marketing of MAPs especially in the high valued international markets requires strong marketing infrastructure and R\&D facilities. Such capitals are usually not easily available in most of the developing countries. The other challenge identified by most of the sources of the study is that herbal medicines are not sold as over-the-counter products in the developed countries hence the need for capital investment in $R \& D$, pre and post-harvest technology and quality products processing, packaging and storage infrastructure $(71 \%)$. Furthermore, seventy-eight percent of the sources of the study were of the view that the import of new technology and equipment will be a solution to the lack of locally manufacturing facilities and equipment.

Currently most of the LDCs are not cultivating the MAPs. Most of the suppliers are actually harvesters of the MAPs from the wild. Therefore the supply potential is thus virtually unknown. Eighty four percent of the focus group participants and other secondary sources indicated that most of the MAPs do not adhere to modern agricultural propagation practices. Another major challenge as indicated by most $(63 \%)$ of the sources of the study is the lack of know-how in processing technologies, lack of regular supplies of plant raw materials in adequate quantities on long-term basis, unavailability of sustainable production processes, lack of institutional capability (63\%) to advice on quality requirements of standardized plant extracts, policy and regulatory mechanisms.

Regarding policy from the South African perspective, medicinal products are controlled by legislation in the medicines and Related Substances Control Act, ${ }^{21}$ including the Pharmacy $\mathrm{Act}^{22}$ and their related regulations and Ethical Rules. The Medicinal Control Council (MCC) is the primary agency in South Africa responsible for control, regulation and registration of all medicinal. The legislative approach for herbal medicines only makes accommodation of registration of medicines in two categories: orthodox and veterinary medicines. ${ }^{19}$ Homeopathic medicine is dealt with under the orthodox category, but complementary medicines, which included African traditional medicine was not adequately covered. African traditional medicine has now been removed from this category and the MCC is reviewing the legislation. Section 14 of the medicines and Related Substance Control Act stipulates that no person shall sell any medicines that need to be registered, unless that medicine has already been registered. ${ }^{23}$ The MCC has accepted the following understanding of herbal medicine for the purpose of registration.

Herbal medicines are finished, labeled medicinal products that contain an active ingredients aerial or under-ground parts of plants or other plant material or combination thereof, whether in the crude state or as plant preparation. An herbal medicine does not include medicines used exclusively in formalized Herbalism or in traditional indigenous herbalist practices. Any company manufacturing registered medicinal products is required to be a pharmaceutical company registered with the MCC, as well as with the South Africa Pharmacy Council. In 1994, the WHO Regional Office for the Eastern Mediterranean published Guidelines for Formulation of National Policy on Herbal Medicines. As the majority of the world population seeks treatment with traditional medical practices, especially herbal medicine, and as herbal medicines are of particular value in gastrointestinal problems, upper respiratory tract ailments, urinary tract diseases and skin diseases, the need to formulate national policies on traditional medicines and to encourage co-operation between Member States in this regard is evident. ${ }^{18}$

In Africa the use of herbal medicine is based on the traditional knowledge and belief. However, knowledge about herbal medicines is very limited in most of the 
developed countries. This limits the usage, consumption and marketability of the plants. It is therefore important to employ a special deliberate systematic approach or strategy to link with end-users in the developed countries to study their use in herbal supplements and herbal remedies manufactured by them, explore the possibility of selling traditional herbal supplements and tonics and lastly, to examine the requirements for marketing traditional medicines.

Last but not the least of the marketing challenges is the lack of value adding to the African Medicinal and Aromatic Plants preparations. It is an established fact that value-adding improves income from the products, however majority of primary producers of herbal medicines in Africa have not as yet moved towards adding value to local natural products. It has been indicated by many researchers that some plants originating from Africa have become sources of important drugs with examples extending to Neostigmine which is made from the Calabar bean being used in treating glaucoma and as an insecticide. ${ }^{24,25}$

\section{Lack of access to information}

About $65 \%$ of the focus group participants in the study and the other secondary sources identified lack of access to information as one of the challenges limiting the development of the African herbal medicine industry. International databases and journals form the major sources of literature for many researchers and knowledge seekers of African herbal medicines and aromatic plants. However, due to lack of finance and other economic priorities institutions do not subscribe to these sources for data/information. It should be emphasized that critical information/data required for technologies and scientific processing of herbal medicines and aromatic plants are not available at the aforementioned sources; many of the sources that contain such important data and information are usually patented and requires money to be granted access.

\section{Human resource development challenge}

Sixty-seven percent of the focus group participants as well as the secondary sources identified lack of modern skills capacity as a major challenge to the development of the MAP industry. More highly qualified specialists in chemical engineering and technology are required if appropriate and proper scientific research in African herbal and aromatic plants are to be undertaken. However, very few scientists in Africa specialize in this field; the services of the few specialists available are also required in other similar industrial sectors, making it a major limitation to the industry's development.

\section{Pressure on the ecology}

The majority $(81 \%)$ of the focus groups and other respondents indicated that the major concern facing African medicinal and aromatic plants' continuous availability, development and use is its survival and reproducing ability for future supply needs. In most of the LDCs the herbal medicinal and aromatic plants usually grow in the wild and harvested without restrictions by traditional herbal medicine practitioners. The plants are harvested sometimes for commercial use; some of the harvesting procedures used are destructive especially where shoots and underground parts are removed incorrectly and become vulnerable to higher temperatures; this may disrupt or curtail the photosynthetic activities of the affected plants. ${ }^{26}$ There is reported evidence of severe decline in herbal medicinal plants in many parts of the world and attributed it to the demand in international trade and not to the supply needed by the indigenous population. ${ }^{27}$ The trade in botanicals is largely unmonitored. This over-exploitative practice without primary cultivation of the plants for regeneration coupled with other factors such as climate change, desertification, bush fires, drought and population growth will cause drastic decline of African medicinal plant resources' genetic diversity and livelihoods of people who depend on plants. Other studies have indicated that demand for medicinal plant-based raw materials is growing and many African medicinal plant species are used in curing more than one disease. ${ }^{28}$

\section{The intellectual property challenge}

The study also found from the secondary sources that intellectual property rights of traditional medicines continue to be one of the major concerns in the Less Developed Countries. It is very difficult for them to be patented, because the plants have been used by many people in many traditional medicines for many years from generation to generation; however, they can be registered as individual or regional trademarks, with unequivocal directions of source. The hindrance to patenting of the African traditional medicines in LDCs are many and varied which include: nonexistence of legislative framework for official recognition of African herbal medicines and their registration and property rights procedures; lack of knowledge about intellectual property rights; high cost of patenting to the African and their institutions; lack of patent experts to advise on requirements for patenting; and the fact that plant materials cannot be patented in their natural form. Traditional healers associations have identified the high costs of filing patent applications as the biggest obstacle to the acquisition of patents by practitioners 
of traditional medicines. ${ }^{29}$ According to the report by the World Intellectual Property Organisation, ${ }^{30}$ holders of indigenous knowledge systems pointed out that the transaction costs of the formal system are beyond the capacity of the majority of informal innovators, hindering their ability to file for patents. Although it is true that plant materials cannot be patented in their natural form, efforts should be made to protect the processes involved in the development of herbal medicine and aromatic products as well as the novel uses of the products.

\section{CONCLUSION}

Major challenges observed from the study included; very low-yielding species, poor quality outputs and poor processing methods. In addition, most MAPs do not adhere to agricultural propagation practices, deterring them as desirable crops. Moreover, there are many differences in traditional medicines so produced in respect of quality. Determining the right medicinal concentrations, dosage and toxicity concerns require highly efficient modern technologies. Other issues of concern revealed in the study included, intellectual property rights, lack of access to information, marketing of products and sustainable conservation.

The cost of setting up a full value chain industry for MAP's includes major investment in research and development in order for the country to best utilise its natural resource despite these hegemonic challenges discussed. Important recommended strategies are that:

Government should come out with clear agricultural policies to establish an information centre that acts as a source of information for producers/harvesters.

Government should work on technical issues concerning African medicinal and aromatic plants such as; promoting the use of research and experts on issues regarding the marketing of the products.

Initiatives from rural and peri-urban community towards African medicinal and aromatic plants should be supported by appropriate assistance from institutions by providing adequate extension services, improving grants, and access to credit inputs. This call for policy proposals that could help addresses the challenges faced by the marketing. The need for improvement in access to markets and market information with respect to African medicinal and aromatic plants should be one of the priorities of governments.

Government should assist in human resource development through mobilization, facilitation and integration of a comprehensive market strategy that will enable African medicinal and aromatic plants producers/harvesters to have greater access to national and international markets. One of the vital necessities of a successful agricultural sector is the availability of reliable, readily available and understandable market information. This enhances producers' decision making and afford them a chance to exploit market opportunities. With the current deregulation of the various control boards, timely market information has become even more important as producers will now have to be more involved in marketing of their produce.

The balance between marketing of inputs and production is vital to guard against the cost price-squeeze syndrome. Supply-side measures help reduce the costs price-squeeze syndrome and lead to sustainable growth of the manufacturing sector. Some of these measures are:

- Support for technological development and diffusion:

- Support for skill development of producers especially young aspiring producers.

- Competitive input prices;

- Support programmes with respect to infrastructural development; and

- Promotion of both internal and export marketing programs.

For production to be effective, the current extension services should be enhanced and given an independent unit with the objective of;

- Awareness on African medicinal and aromatic plants

- Market coordination with respect to African medicinal and aromatic plants

- Information centre and

- Capacity building, especially for young producers

The government is expected to facilitate the creation of new opportunities for the established and new entrant producers by developing support systems and infrastructure and by the provision of training, marketing information and other support services.

\section{ACKNOWLEDGEMENT}

We would like to acknowledge the Department of Trade and Industry for allowing us to conduct this study, The College Research Committee (College of Agriculture and Environmental Sciences, University of South Africa) for the financial support. 


\section{CONFLICT OF INTEREST}

The authors declare no conflict of interest.

\section{ABBREVIATION USED}

MAP: Medicinal and aromatic plants; NGP: New growth path; AFF: Agriculture, forestry and fisheries; GDP: Gross domestic product ; EU ; European Union ; Agritex: Agricultural Extension; OECD: Organization for European co-operation and development; R\&D: Research and development; CAM: Complementary and alternative medicine; LDC: Less developed countries; MCC: Medical control council.

\section{REFERENCES}

1. Bell TW. Unemployment in South Africa. Institute for Social \& Economic Research. University of Durban-Westville. 1984.

2. Altbekker A, Storme E. Graduate unemployment in South Africa: A much exaggerated problem. Centre for Development and Enterprise. Johannesburg, South Africa. 2013.

3. Industrial Policy Action Plan. Government of South Africa. Department of Trade and Industry. 2011. https://www.environment.gov.za/sites/default/files/ docs/ipap.pdf

4. National Agricultural Marketing Council annual report 2008. http://www.namc. co.za/upload/annual_reports/ANNUALREP2008FINALPRINTED130708. doc.pdf

5. Economic Sciences. The declining contribution of agriculture to GDP: Is the role of agriculture becoming less important? NDA, PTA. 2010. http://www. nda.agric.za/docs/Economic_analysis/DecliningContributionOfAgricToGDP. doc.

6. European Parliament Committee on Agriculture and Rural Development 2010. The single payment scheme after 2013: new approach-new targets. http://www.capreform.eu/wp-content/uploads/2010/05/EST31208.pdf

7. Organisation for Economic Co-operation and Development. OECD review of Agricultural Policies 2006: ISBN-92-64-03679-2. http://www.fanrpan.org/ documents/d00456/1-OECD_review_agricultural_policies_SA.pdf

8. Fan S, Zhang X, Rao N. Public expenditure, growth, and poverty reduction in rural Uganda, DSGD discussion papers, International Food Policy Research Institute (IFPRI) 4, International Food Policy Research Institute (IFPRI). 2004.

9. Goff S. Worldroom.tamu.edu, Constraints and opportunities for Agricultural development in Sub-Saharan Africa. 2007. http://worldroom.tamu.edu/ Workshops/Africa07/Agriculture-Sub-Saharan Africa/Constraints $\% 20$ and\%20 Opportunities\%20for\%20Agricultural\%20Development\%20i.ppt.

10. Okigbo RN, Anuagasi CL, Amadi JE. Advances in selected medicinal and aromatic plants indigenous to Africa. J Med Plant. 2009; 3(2): 86-95

11. Slikkerveer LJ. The challenge of non-experimental validation of mac plants: towards a multivariate model of transcultural utilization of medicinal. aromatic and cosmetic plants: in: Bogers RJ, Craker LE, Lange D. (eds.), Medicinal and Aromatic Plants, ${ }^{\odot}$ Springer. Printed in the Netherlands. 2006. 1-28.
12. Slikkerveer LJ. The challenge of non-experimental validation of mac plants: towards a multivariate model of transcultural utilization of medicinal, aromatic and cosmetic plants. Frontis 17, 2006. 1-28.

13. Department of Science and Technology. The Bio-economy strategy. 2013. ISBN number 978-1-919966-06-9 http://www.pub.ac.za/files/Bioeconomy\%20 Strategy.pdf.

14. Government of South Africa, Department of Trade and Industry. 2010. http:// www.poa.gov.za/Outcome4/.../New\%20Growth\%20Path.pdf

15. Kumari P, Chandra JG, Mohan TL. Biodiversity status, distribution and use pattern of some ethno-medicinal plants. Int J Conser Sci. 2012; 3(4): 309.

16. Kideghesho JR, Nyahongo JW, Hassan SN, Tarimo TC, Mbije NE, et al. Factors and ecological impacts of wildlife habitat destruction in the Serengeti ecosystem in northern Tanzania. Afr J Envir Ass Man. 2006; 11: 17-32.

17. Adotey JP, Adukpo K, Opoku GE, Armah FA. A review of the ethnobotany and pharmacological importance of Alstoniaboonei De Wild (Apocynaceae). Int Scholarly Res Notices. 2012; 2012: 587-160. doi:10.5402/2012/587160

18. Mohamed SE. Pharmacological investigations of Solenostemma argel leaves. Global J Trad Med Sys. 2013; 2(1): 28-36.

19. Zhang X. Regulatory Situation of Herbal Medicines A worldwide Review. World Health Organization. 1998; 1-45 www.pitdc.org.tw.

20. Agricultural Marketing Resource Center. Direct Marketing of Agricultural Produce; lesson 3, value-added Agricultural Profile. lowa State University. 2007. http://www.agmrc.org/media/cms/vaalesson3_af2708a5243a3.pdf

21. Medicines and related substances Act 101 of 1965. http://www.hpcsa.co.za/ Uploads/editor/UserFiles/downloads/legislations/acts/medicines_and_ related_sub_act_101_of_1965.pdf

22. Pharmacy Act 53 of 1974 . Regulations relating to the practice of pharmacy. http://www.saflii.org/za/legis/num_act/paa1997178.pdf

23. Parliamentary Act. Parliament Act 132 of 1998; the South African Medicines and Medical Devices Regulatory Authority Bill. 1998.

24. Gurib-Fakim A. Medicinal plants: traditions of yesterday and drugs of tomorrow. Mol Aspects Med. 2006; 27(1):1-93.

25. Rukangira E. Medicinal plants and traditional medicine in Africa: Constraints and challenges. Sustain Dev Int. 2001; 4: 179-84. www.ljemail.org/reference/ ReferencesPapers.aspx?ReferencelD $=493589$

26. Kala CP, Dhyani PP, Sajwan BS. Developing the Medicinal Plants Sector in Northern India: challenges and opportunities. J Ethnobiol Ethnomed. 2006; 2 : 32. http://www.ncbi.nlm.nih.gov/pmc/articles/PMC1562365/\#

27. Lange D. Medicinal and Aromatic Plants: Trade, Production, and Management of Botanical Resources Proc. XXVI IHC-Future for Medicinal and Aromatic Plants. Acta Horticulture. 2004; 629: 177-97. doi: 10.17660/ ActaHortic.2004.629.25 http://dx.doi.org/10.17660/ActaHortic.2004.629.25

28. Phondani PC. Worth of Traditional Herbal System of Medicine for Curing Ailments Prevalent Across the Mountain Region of Uttarakhand, India. J App Pharma Sci. 2011; 1(9): 81-6.

29. Wilder R. Protection of Traditional Medicine. ICRIER Working Paper No. 66. Partner, Powell, Goldstein, Frazer \& Murphy LLP Washington, D.C., USA. 2001.

30. World Intellectual Property Organisation. Intellectual property needs and expectations of traditional knowledge holders. WIPO report on fact finding mission on Intellectual Property and Traditional Knowledge. Geneva. 2001. 